\title{
CMA1 Gene
}

National Cancer Institute

\section{Source}

National Cancer Institute. CMA1 Gene. NCI Thesaurus. Code C124243.

This gene plays a role in both extracellular matrix degradation and vasoactive peptide formation. 